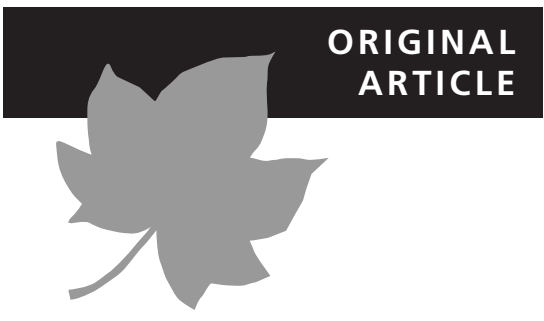

\title{
Global bottlenecks in the distribution of marine Crustacea: temperature constraints in the family Lithodidae
}

\author{
Sally Hall* and Sven Thatje
}

School of Ocean and Earth Science, National Oceanography Centre, University of Southampton, Southampton SO14 3ZH, UK

\begin{abstract}
Aim Members of the crustacean family Lithodidae share preferences for coldwater environments; however, the specific role of temperature in governing lithodid biogeography has not been examined to date. In the present study this relationship was quantified through the analysis of habitat data, and the results were interpreted in the light of previous physiological studies. It was hypothesized that lineage-specific temperature thresholds underlie differences in the distribution of the two lithodid subfamilies.
\end{abstract}

Location The family Lithodidae is divided into the subfamilies Hapalogastrinae and Lithodinae. The Hapalogastrinae inhabit depths of between 0 and $200 \mathrm{~m}$ in the North Pacific. The Lithodinae are distributed globally in the deep sea, with a few genera occurring intertidally at high latitudes.

Methods Descriptions of 86 species of lithodids, sampled at 627 locations worldwide, were obtained from a wide range of published and original sources. For each specimen, the water temperature at the time and locality of collection was recorded. Molecular sequence data for the 16S, cytochrome $c$ oxidase subunit I (COI) and $28 \mathrm{~S}$ genes were analysed to construct a phylogenetic tree for the major lithodid genera, using a maximum likelihood method in the program PAUP $^{\star}$. Further analyses examined the link between the habitat temperature range and the position of taxa within the lithodid phylogeny.

Results Phylogenetic evidence indicated that the deep-water lithodid lineages had ancestors that inhabited the coastal waters of the North Pacific. Adults of North Pacific lithodid taxa were found in regions where water temperatures ranged from 0 to $25^{\circ} \mathrm{C}$; however, deep-water lineages of the Lithodinae were excluded from waters exceeding temperatures of $13^{\circ} \mathrm{C}$. Despite the higher temperatures tolerated by adults, North Pacific intertidal/subtidal genera were restricted to regions that had water temperatures lower than $16^{\circ} \mathrm{C}$ during periods of larval development.

Main conclusions Temperature has restricted the range of most shallow-water genera of Lithodidae to the coastline of the North Pacific since the early history of the family. Distribution in these groups remains constrained by the detrimental effects of temperature extremes on early life-history stages. Deep-water lineages moved away from seasonal temperature fluctuations, and underwent at least three radiations into water bodies outside the North Pacific. Species from within the deep-water lineages currently live close to the threshold of their temperature tolerance in the Southern Ocean, and their future distribution may be affected by increases in ocean temperature.

\section{Keywords}

Climate change, Crustacea, deep sea, global distribution, Lithodidae, North Pacific, physiological threshold, temperature tolerance.

Southampton SO14 3ZH, UK.

E-mail: smh57@noc.soton.ac.uk

${ }^{\star}$ Correspondence: Sally Hall, National 


\section{INTRODUCTION}

The anomuran family Lithodidae is a taxon of marine decapod crustaceans with a crab-like body form. It includes some of the largest predatory crustaceans in the ocean, and some species are the targets of large-scale fisheries in several high-latitude regions (Lovrich \& Vinuesa, 1993, 1999; Armistead et al., 2000). The potential for opening new fisheries (Jorgensen et al., 2005), as well as the evidence of rapid habitat colonization for some lithodid species (Orlov \& Ivanov, 1978; Thatje et al., 2005; Aronson et al., 2007), has inspired ongoing research on this group.

Ten out of the 14 lithodid genera (nomenclature follows Macpherson, 1988; unless otherwise stated) are restricted to the coast of North America and linked island chains, at depths shallower than $200 \mathrm{~m}$. The Hapalogastrinae Brandt, 1850, share a small adult body size, and range from the intertidal zones down to $100 \mathrm{~m}$ water depth (Zaklan, 2002a,b). Larvae are planktotrophic and are released seasonally. Adults of the Hapalogastrinae are non-migratory (Goshima et al., 1995; Zaklan, 2002b).

Some North Pacific genera of the subfamily Lithodinae Samouelle, 1819, also have planktotrophic modes of larval development. Paralithodes camtschaticus (Tilesius, 1815) for example, coordinates the release of planktotrophic larvae with a short, seasonal plankton bloom. It is likely that vertical migration in Paralithodes occurs to accommodate temperature requirements, which vary according to life-history stage (Stone et al., 1992; Stevens, 2006).

The majority of the species in the Lithodinae ( 88 out of 109 described lithodid species) belong to three genera (Paralomis, Lithodes and Neolithodes; Macpherson, 1988), occurring as deep as $3000 \mathrm{~m}$ in most of the world's oceans. According to all available evidence, these groups have facultative or fully lecithotrophic larval development (Shirley \& Zhou, 1997; Lovrich \& Vinuesa, 1999; Paul \& Paul, 2001; Thatje et al., 2005; Saborowski et al., 2006).

The concept of a deep-sea bottleneck in the radiation of lithodids has been proposed by several authors over the last 150 years (Bouvier, 1895; Makarov, 1962; Zaklan, 2002a). These authors have hypothesized that, commencing from a shallow-water origin, lithodids followed one route of radiation through a shallow-water pathway, and one through deep water. Ecological or physiological factors seem to have limited the range of the shallow-water lineages, resulting in an endemic North Pacific subfamily. Isothermal submergence at the poles is a phenomenon known from several other taxa with bipolar distributions (Andriashev, 1986; Harrison \& Crespi, 1999; Briggs, 2003; Raupach et al., 2008). This principle may explain how some lineages followed a deep-sea route out of the North Pacific and into other water bodies (Bouvier, 1895; Makarov, 1962; Zaklan, 2002a).

\section{Physiological temperature thresholds}

Factors affecting growth, particularly during the larval cycle and early adult stages, are widely studied because of their relevance for fisheries (Kurata, 1960; Vinuesa et al., 1985; Shirley \& Shirley, 1989; Calcagno et al., 2005). Empirical studies have focused almost exclusively on the lithodid species of actual or potential commercial interest ( $P$. camtschaticus, Paralithodes brevipes, Lithodes santolla and Paralomis granulosa). Significantly reduced survival to first moult is reported when larvae of these species are exposed to temperatures above $13^{\circ} \mathrm{C}$ (Nakanishi, 1981, 1985; Vinuesa et al., 1985) or $15^{\circ} \mathrm{C}$ (Kurata, 1960; Shirley \& Shirley, 1989; Calcagno et al., 2005). No larval development occurs at $-1.8^{\circ} \mathrm{C}$ in P. camtschaticus (Nakanishi, 1981), and it is suggested that minimal requirements for growth are around 0-2 ${ }^{\circ} \mathrm{C}$ (Shirley \& Shirley, 1989; Thatje et al., 2005). Optimal temperature for larval growth is between 5 and $10^{\circ} \mathrm{C}$, provided salinity is above $20 \mathrm{ppt}$. There is no published experimental evidence for temperature thresholds in the nonmigratory hapalogastrines, but it is hypothesized that the restriction to the shallow waters of the North Pacific is also related to temperature.

\section{Life-history adaptations to temperature}

Low temperatures are known to slow metabolic rate and decrease oxygen consumption. Calcagno et al. (2005) demonstrated that lower environmental temperatures slowed development to maturity in P. granulosa. Nakanishi (1985) and Kurata (1960) reported temperature-determined increases in larval intermoult periods in $P$. camtschaticus.

Pre-megalopal moults are consistently fewer in Lithodinae (2-4) than in Hapalogastrinae (4-5), but there does appear to be some plasticity in the larval moult cycle (Crain \& McLaughlin, 2000). Both groups demonstrate a reduction in moult number from that of the presumed ancestral state (Cunningham et al., 1992; Zaklan, 2002a; McLaughlin et al., 2007). This may be an adaptation that promotes survival over the protracted development times seen in colder waters (Thatje, 2004).

Compared to ecologically similar crustaceans, lithodids have extremely protracted larval hatching events. In groups of lithodids with planktotrophic larvae, spawning is highly synchronized with season, but the hatching process can last for more than 1 month. Paralithodes camtschaticus (Lithodinae) begins hatching when environmental water temperatures reach $4^{\circ} \mathrm{C}$, and individual hatching rhythms last up to 2 months (Stevens, 2006). Specimens belonging to the hapalogastrine genus Placentron Schalfeew, 1892 take more than 17 days to complete larval release (Crain \& McLaughlin, 2000). Individuals belonging to the widespread genera Lithodes and Paralomis have hatching durations of between 13 and at least 61 days in experimental conditions at $6^{\circ} \mathrm{C}$ (Thatje et al., 2003). Hatching events can be completely asynchronous in deep-water species of these genera (Reid et al., 2007). In contrast, other decapods can have highly synchronous hatching events lasting only minutes or hours, which are often triggered by extrinsic factors (Forward, 1987; Ziegler \& Forward, 2005; Lovrich \& Thatje, 2006). Protracted spawning 
results in fewer larvae being released per day - a behaviour that could increase overall fitness in an unpredictable environment. This may be particularly crucial in species that invest long periods of time in brooding (up to 2 years in some known cases; Lovrich \& Vinuesa, 1999) and have a low fecundity because of the cost of increased maternal energy investment into single offspring (Thatje, 2004; Morley et al., 2006).

Despite the substantial evidence for cold-water preferences or restrictions (Zaklan, 2002a; Thatje et al., 2005), the exact nature of the relationship between biogeography and temperature has not yet been examined in this group. This study tests the hypothesis that lineage-specific temperature tolerances influence the distribution of lithodid subfamilies.

\section{MATERIALS AND METHODS}

\section{Data sources}

Data were gathered from three sources, as follows:

1. One hundred and ninety-seven published records of lithodids were sourced from peer-reviewed journals and other literature. Identity was verified by S. Hall from descriptions and pictures, or by inspection where samples were deposited in museums. If species identity was ambiguous, data were included only for genus-level analyses.

2. Five hundred and two specimens (mostly unpublished records) were examined from museum collections in the Natural History Museum (NHM), London; Muséum National d'Histoire Naturelle (MNHN), Paris; Senkenberg Museum, Frankfurt; and the United States National Museum of Natural History, Washington.

3. Fifty-six specimens with associated environmental data were obtained courtesy of commercial vessels or scientific cruises, from locations in the Southern Ocean, South America and West Africa.

For each specimen studied, the depth, location and date of sample collection were noted. Most records were for crab stages; however, a few larval records were included. The study included $82 \%$ of the lithodid species (86/109) described to date (Macpherson, 1988; Zaklan, 2002a), with 65\% of these species represented by more than 10 sample sites. Data from 627 worldwide sample locations (Fig. 1) were used.

Water temperature at the time of sampling was obtained from cruise reports where possible. Otherwise, temperatures were estimated, based on time of year, depth and location. The

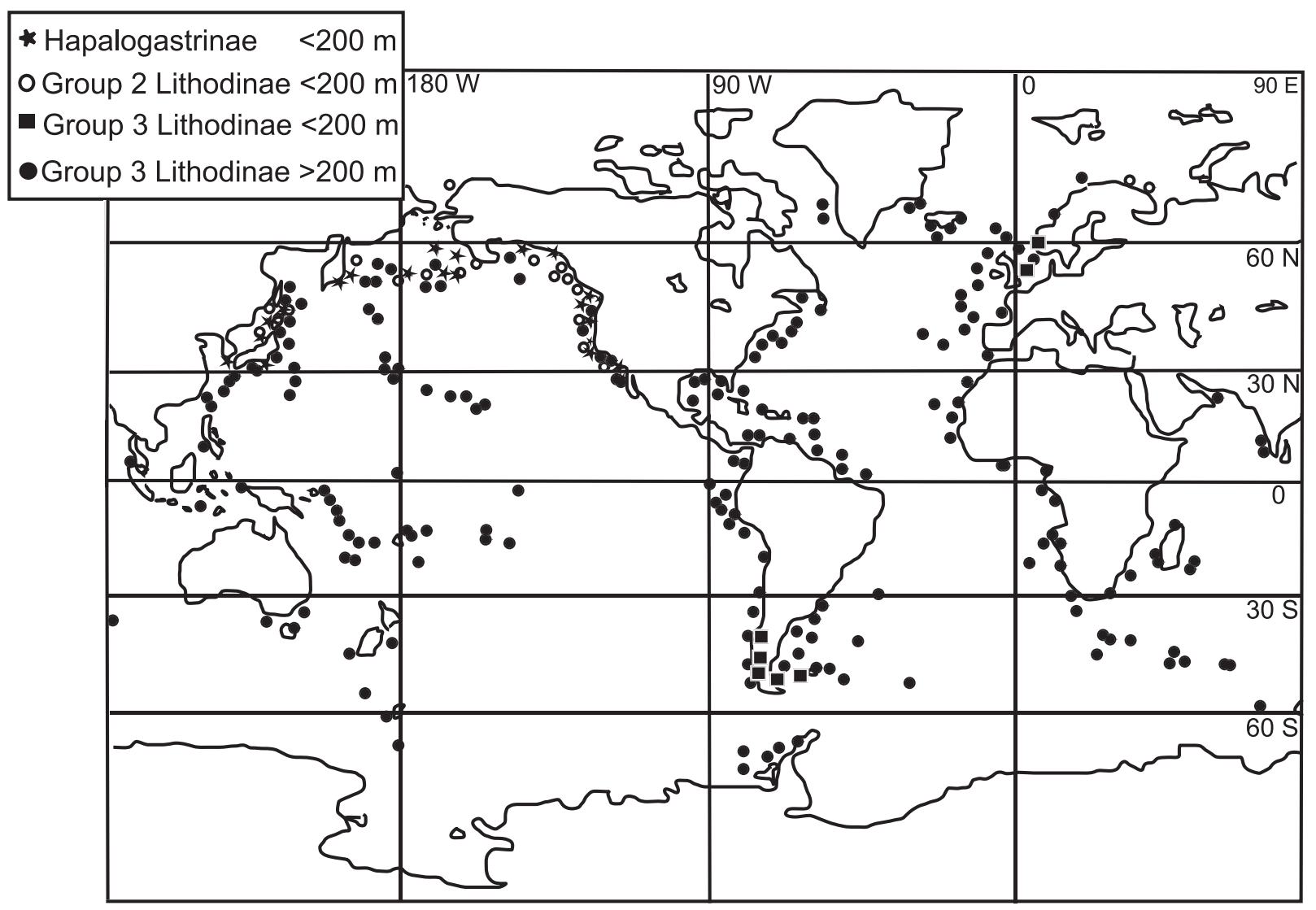

Figure 1 Map of sample locations of lithodids classified by habitat depth and phylogenetic position. Group 1: Hapalogastrinae; Group 2: Lithodinae from genera that are endemic to the North Pacific; Group 3: Lithodinae from genera that are not endemic to the North Pacific (Paralomis, Lithodes, Neolithodes, Glyptolithodes), categorized by habitat depth. Positions of markers represent sample sites. Markers falling within $50 \mathrm{~km}$ of another sample site of the same type were omitted for clarity. 
majority of the climatic data were taken from the National Oceanographic Data Centre World Ocean Atlas 2005 (Locarnini et al., 2006) and the National Oceanic and Atmospheric Administration - Earth System Research Laboratory (NOAA-ESRL), Physical Sciences Division (http:// www.cdc.noaa.gov/). Full datasets are available upon request from the authors.

\section{Molecular phylogeny}

A reconstruction of phylogeny for the lithodid genera (Fig. 2) was created using molecular data from the GenBank database, largely from Zaklan (2002a), in addition to original molecular data for the 16S, cytochrome $c$ oxidase subunit I (COI) and 28S genes (for full details see Appendix S1 in Supporting Information). A consensus tree was obtained using a maximum likelihood method in the program PAUP $^{*} 4.0 \mathrm{~b} 10$ (Swofford, 2000). Bootstrap values for 1000 replicates were displayed at the nodes (Fig. 2), and nodes supported in fewer than $50 \%$ of replicates were collapsed to produce polychotomies. Outgroups were chosen from related groups within the anomura: Pagurus bernhardus was used following Cunningham et al. (1992) and a species of Aegla (Perez-Losada et al., 2004) represents other anomuran groups. Inclusion of other anomuran outgroups made no difference at any of the significant nodes.

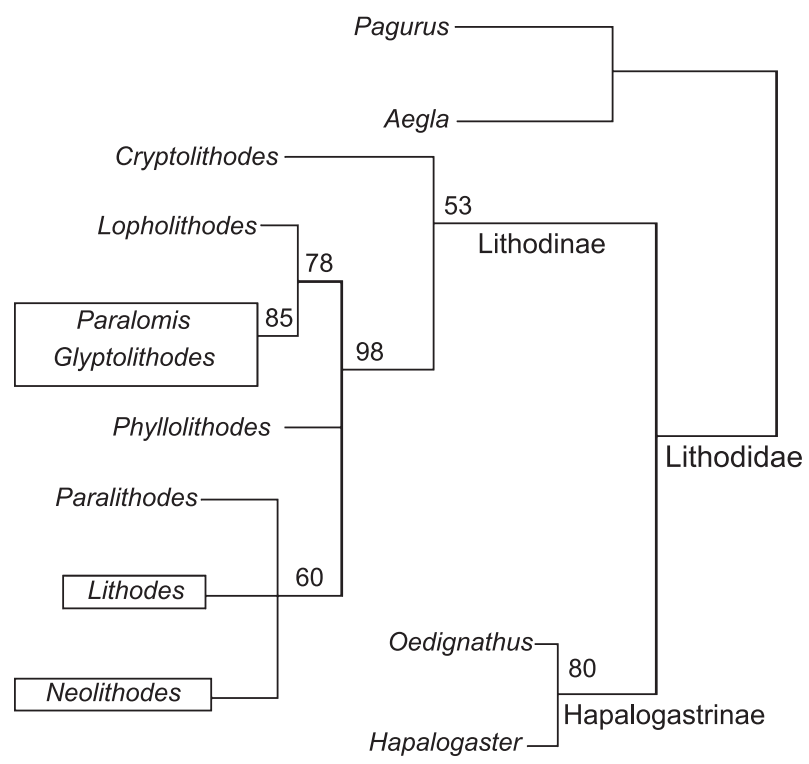

Figure 2 Maximum likelihood tree created with PAUP ${ }^{\star} 4.0 \mathrm{~b} .10$ (Swofford, 2000) for species representing 10 genera of Lithodidae. Analyses were based on sequences of 16S, COI (mitochondrial) and $28 \mathrm{~S}$ (nuclear) genes from the GenBank database and original datasets (see Appendix S1). Node labels are bootstrap values for 1000 replicates. Nodes supported in fewer than $50 \%$ of replicates were collapsed. Clades representing families and subfamilies are labelled below the node. Genera within which members occur below $200 \mathrm{~m}$ and/or outside the Pacific Ocean are distinguished with a black box. Outgroup genera from other anomuran families (Pagurus and Aegla) were used to root the tree.

\section{Analysis}

\section{Latitudinal and bathymetric data}

Records of shallowest specimen depth were compared with sample-site latitude. Most species had a range covering several tens of degrees of latitude; however, within species there was no significant $\left(r^{2}<0.05\right)$ difference in depth across sites of differing latitude. This observation justified the pooling of data from different sample locations into a mean latitude for each species. The shallowest depth was calculated as the 90th percentile of records within species groups (points, Fig. 3). Full latitudinal and depth ranges for each species were also obtained, and pooled within subfamily groups (dashed line and solid line, Fig. 3).

\section{Depth, location and temperature data}

Records of depth and local temperature for individual samples were compared - data were not pooled into species groups for this analysis. Mean seasonal variation in temperature was projected for each sample location (Fig. 4). Estimates of maximal and minimal global temperature profiles were taken from the World Ocean Atlas 2005 (Locarnini et al., 2006), excluding data from inland or sheltered shallow seas that have atypical temperature profiles, and in which lithodids have not been found. This provided a diagrammatic sense of the range of temperatures typically found at different depths in world oceans.

To investigate patterns of variation between lineages, data points were classified in all analyses according to their position in the molecular phylogeny (Fig. 2), as follows:

1. Subfamily Hapalogastrinae.

2. Members of genera within the subfamily Lithodinae, which share larval planktotrophy and shallow $(<200 \mathrm{~m})$ North Pacific habitats with the Hapalogastrinae.

3. Lithodinae belonging to genera within which members are found deeper than $200 \mathrm{~m}$ and/or outside the North Pacific: Paralomis, Lithodes, Neolithodes and Glyptolithodes.

\section{Southerly range boundaries for North Pacific subtidal populations}

In order to examine the nature of temperature thresholds in lithodids, the species tolerant of temperatures higher than $13^{\circ} \mathrm{C}$ were considered in further detail. All of these species occur exclusively in the North Pacific (Table 1). The most southerly populations of Lithodidae are found along the oceanic coast of Baja California, Mexico $\left(29^{\circ} 47 \mathrm{~N} ; 15 \mathrm{~m}\right.$ deep). Detailed weekly average temperature profiles are available for this region between August 1992 and 2008, courtesy of the NOAA-ESRL (http://www.cdc.noaa.gov/). For each month from 1992 to 2002, the temperature in the subtidal range (5-15 m) was recorded for latitudes 26, 30, 32, 34 and $36^{\circ} \mathrm{N}$ (Fig. 5). This enabled the seasonality of larval release to be examined with respect to water temperature. Hatching 
Figure 3 Variation in the shallowest depth of lithodid species according to latitude. Data points represent the mean latitude and 90th percentile of depth for each of 86 lithodid species. Species are classified according to subfamily and habitat depth. Full ranges of depth and latitude for species within the Hapalogastrinae are bounded by a solid line, and within the Lithodinae by a dashed line.

Figure 4 The effect of temperature on the depth distribution of the two subfamilies of Lithodidae. Points represent individual subpopulation samples. Temperature is based either on an estimate monthly average at sample location, or on data recorded directly at the time of sampling. Mean yearly (seasonal) variation at each sample site is represented by horizontal error bars. Estimates of maximal (A) and minimal (B) global temperature/depth profiles were taken from World Ocean Atlas 2005 (Locarnini et al., 2006), and exclude data from inland or sheltered shallow seas. Data points were shaded according to subfamily and habitat depth. Dashed grey lines at temperatures of $0^{\circ}, 13^{\circ}$ and $15^{\circ} \mathrm{C}$ indicate estimates of larval survival thresholds, which were taken from published physiological experimental work.
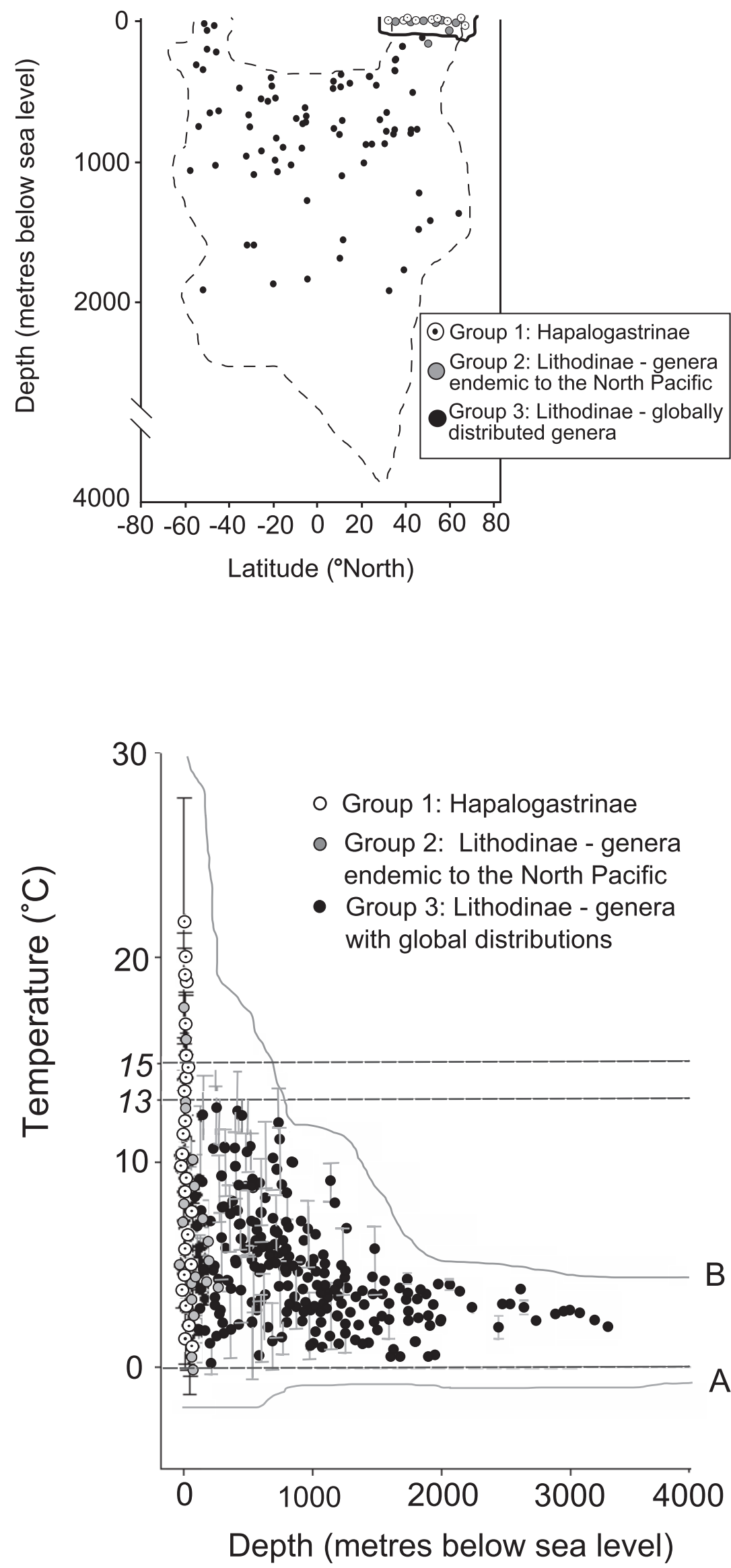


\begin{tabular}{|c|c|c|c|}
\hline Species & $\begin{array}{l}\text { Most southerly range extent } \\
\text { along west coast America }\end{array}$ & $\begin{array}{l}\text { Depth } \\
\text { range }(\mathrm{m})\end{array}$ & Hatching period \\
\hline \multicolumn{4}{|l|}{ Subfamily Lithodinae } \\
\hline Phyllolithodes papillosus & Monterey, CA $36.35^{\circ} \mathrm{N}$ & $0-183$ & March-May \\
\hline Rhinolithodes wosnessenskii & Crescent City, CA $41.45^{\circ} \mathrm{N}$ & $6-73$ & March \\
\hline Sculptolithodes derjugini & N/A & $20-35$ & - \\
\hline Cryptolithodes expansus & British Columbia & $50-60$ & - \\
\hline Cryptolithodes sitchensis & San Diego, CA $32.43^{\circ} \mathrm{N}$ & $0-37$ & - \\
\hline Cryptolithodes typicus & Monterey, CA $36.35^{\circ} \mathrm{N}$ & $0-45$ & March-April \\
\hline Paralithodes brevipes & N/A & $0-66$ & March-April \\
\hline Paralithodes camtschaticus & N/A & $5-200$ & February-May \\
\hline \multicolumn{4}{|l|}{ Subfamily Hapalogastrinae } \\
\hline Acantholithodes hispidus & Monterey, CA $36.35^{\circ} \mathrm{N}$ & $0-245$ & - \\
\hline Dermaturus mandtii & N/A & $0-72$ & - \\
\hline Hapalogaster cavicauda & Isla San Jeronimo, Mexico $29.47^{\circ} \mathrm{N}$ & $0-15$ & - \\
\hline Hapalogaster dentata & N/A & $0-180$ & February-March \\
\hline Hapalogaster grebnitzkii & Humboldt Bay, CA $40.46^{\circ} \mathrm{N}$ & $0-90$ & - \\
\hline Hapalogaster mertensii & Puget Sound, WA $48^{\circ} \mathrm{N}$ & $0-55$ & February-March \\
\hline Oedignathus inermis & Pacific Grove, CA $36.35^{\circ} \mathrm{N}$ & $0-15$ & February-March \\
\hline Placetron wosnessenskii & Puget Sound, WA $48^{\circ} \mathrm{N}$ & $0-110$ & March \\
\hline
\end{tabular}

Table 1 Distributional data for species belonging to genera of Lithodidae endemic to the North Pacific Ocean. These data were obtained predominantly from Zaklan (2002b) and the collections of the United States National Museum of Natural History (USNM).

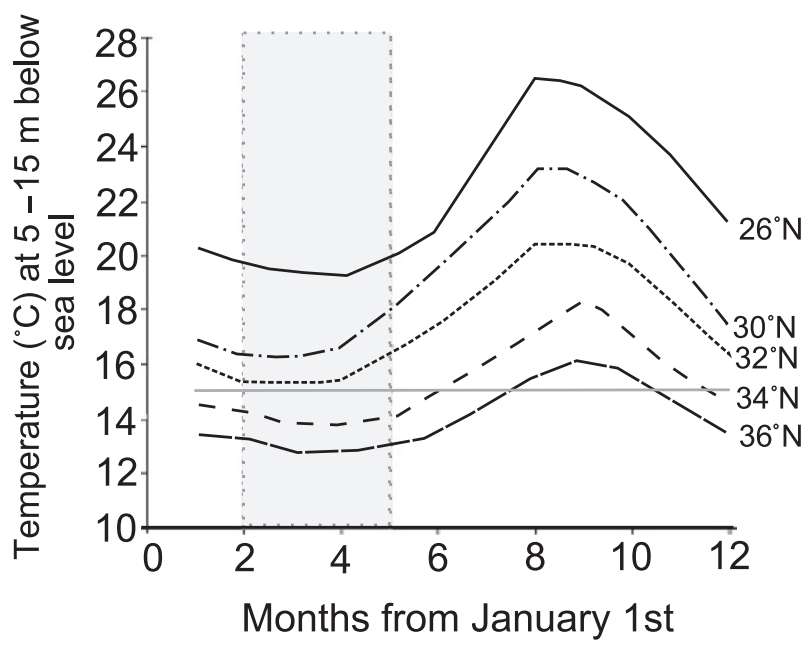

Figure 5 Subtidal temperatures along the coast of California. For each month from 1992 to 2002, the average temperature in the subtidal range $(5-15 \mathrm{~m})$ was recorded for latitudes $26,30,32,34$ and $36^{\circ} \mathrm{N}$ (NOAA-ESRL). A projection at a temperature of $15.5^{\circ} \mathrm{C}$ indicates the maximum, empirically predicted, larval survival threshold. Shading blocks out the months February-May, which represent an estimate of the period during which lithodid larvae would hatch and develop to the megalopal stage at $9^{\circ} \mathrm{C}$ (from Crain \& McLaughlin, 2000; Zaklan, 2002b). This period may be shorter at the elevated temperatures considered here.

seasons for North Pacific lithodids were similar throughout the group, occurring between February and May (Table 1; Zaklan, $2002 \mathrm{~b})$. In addition, the locations of the coastal $15.5^{\circ} \mathrm{C}$ isotherms between February and May were calculated from the NOAA-ESRL (http://www.cdc.noaa.gov/) dataset for North America (Fig. 6). A comparison was then made between the latitude of the most southerly lithodid populations and the fluctuating positions of the subtidal $15.5^{\circ} \mathrm{C}$ isotherm.

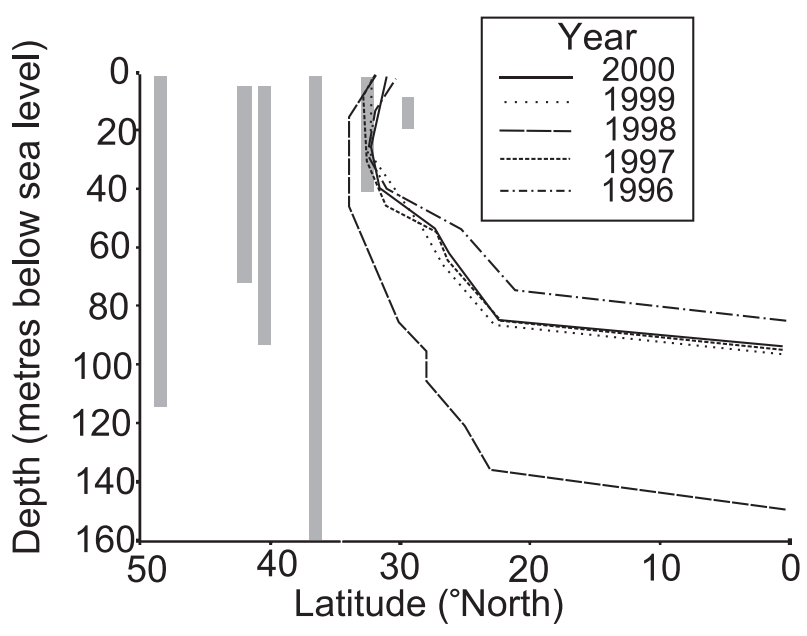

Figure 6 The most southerly records of subtidal Lithodidae on the North American Pacific coastline in relation to the spring $15.5^{\circ} \mathrm{C}$ isotherm. Dashed line-plots represent the location, to the nearest $0.5^{\circ}$ latitude, of the $15.5^{\circ} \mathrm{C}$ isotherm (NOAA-ESRL) between February and May within $100 \mathrm{~km}$ of the west coast of North America. One plot per year from 1996 to 2000 is displayed. In addition, the location of the most southerly sample sites and depth ranges of species (Table 1) along the west coast of North America are indicated with grey blocks. Please note that some of these overlap on the diagram.

\section{RESULTS}

\section{Temperature}

\section{Latitudinal bathymetry clines}

A distributional bottleneck (Bouvier, 1895; Makarov, 1962; Zaklan, 2002a) separated 10 genera occurring at shallow 
northern latitudes from four deep-water genera: Neolithodes, Lithodes, Paralomis and Glyptolithodes. All lithodids appeared to be competitively or physiologically excluded from waters shallower than $400 \mathrm{~m}$ deep between $30^{\circ} \mathrm{N}$ and $40^{\circ} \mathrm{S}$ (Fig. 3). In addition, a trend in emergence from the deep sea could be seen towards high southern latitudes $\left(41-55^{\circ} \mathrm{S}\right)$ in the genera Lithodes and Paralomis, where shallower distributions were largely coincident with the cold PeruChile upwelling zone.

\section{Temperature thresholds}

GROUP 1: The Hapalogastrinae are non-migratory and endemic to the North Pacific intertidal/subtidal zones. This study confirmed that adults of the Hapalogastrinae inhabit water with a much larger range of temperatures (from $0^{\circ} \mathrm{C}$ in the northern Sea of Okhotsk to $25^{\circ} \mathrm{C}$ off the coast of California) than do the adults of the Lithodinae. However, experimental evidence of defined temperature thresholds has been shown only for larval stages. Analyses of local temperature data (Figs 5 and 6) indicated some range limitation in response to water temperature during the larval hatching and development period. Over a sample period of 10 years, the water temperature at the most southerly subtidal sample locations dipped to $16.5^{\circ} \mathrm{C}$ (from summer maxima of $25^{\circ} \mathrm{C}$ ) for the duration of hatching and larval development [6787 days March-May (from Crain \& McLaughlin, 2000; Zaklan, 2002b)]. Hapalogaster cavicauda was the most southerly recorded species, inhabiting waters that were usually within $1^{\circ} \mathrm{C}$ of the spring $15.5^{\circ} \mathrm{C}$ isotherm (Fig. 6). The position of this isotherm varied by several degrees of latitude annually (Fig. 6), and most of the species were only found north of this fluctuation.

GROUP 2: The Lithodinae (including those not inhabiting the deep sea) have experimentally determined physiological temperature thresholds at $0.5^{\circ} \mathrm{C}$ and $13-15^{\circ} \mathrm{C}$. Subtidal North Pacific species of Lithodinae appeared to have a similar distributional range to those shallow-water species of Hapalogastrinae. This may be an indication of a shared ancestral trait.

GROUP 3: For those genera occurring globally (highlighted, Fig. 2), there appeared to be little effect of temperature on range below depths of $1000 \mathrm{~m}$. Most temperatures encountered at depth were within the predicted thresholds for the subfamily.

At depths shallower than $500 \mathrm{~m}$, distributions were restricted at both ends of the temperature scale, with limits at 0 and $13^{\circ} \mathrm{C}$. At the shallowest, warmest locations in which these groups were found, seasonal temperature fluctuations occurred. At some sample locations, temperature would be expected to approach a maximum of $15^{\circ} \mathrm{C}$ over the course of a typical year. Vertical migratory behaviour (Miquel et al., 1985; Abelló \& Macpherson, 1991; Paul \& Paul, 2001) in relation to the reproductive cycle might be explained by the narrower temperature tolerances of early growth stages.
At the lower end of the temperature scale, it has been reported that members of the subfamily Lithodinae inhabit some of the relatively warmer waters around Antarctica (estimated to be between 0.5 and $1.5^{\circ} \mathrm{C}$; Klages et al., 1995), including the contintental slope in the Bellingshausen Sea (Arana \& Retamal, 1999; Raso et al., 2004; Thatje et al., 2008). There were areas of the Southern Ocean (Figs 1 and 3, minimum temperature line) in which lithodids were not present, particularly the Weddell Sea and the Antarctic continental shelves (see Discussion).

\section{DISCUSSION}

The phylogeny (Fig. 2) indicates that the lithodid ancestors were shallow/subtidal animals in the North Pacific with planktotrophic larvae. This substantiates the hypothesis (Bouvier, 1896; Makarov, 1962) that a movement from the North Pacific to the global deep sea was important in lithodid evolutionary history. Lecithotrophy in larvae is unlikely to be ancestral to planktotrophy according to the prevailing ecological theories (Strathman, 1978), and this offers further support to our conclusion.

Protracted hatching and a cold-tolerant physiology are shared by all Lithodidae. These features are likely to be the result of a common adaptive history in a cold and unpredictable environment. From such a common ancestor, the subfamilies Hapalogastrinae and Lithodinae progressed along diverging evolutionary pathways.

\section{Subtidal groups}

The Hapalogastrinae inhabit a wide range of shallow-water environments. The results here indicate that adult Hapalogastrinae tolerate higher temperatures than do the adults of the Lithodinae. Despite the wider range of temperature tolerance, the Hapalogastrinae and some genera of the Lithodinae are restricted to the North Pacific. Data presented here show that non-migratory adults are tied to areas where seasonal temperature drops (or rises) to a level optimal for larval survival (at least during the months of hatching and larval development; Crain \& McLaughlin, 2000).

It is conceivable that the North Pacific Hapalogastrinae were once more widespread and were subject to a subsequent rangerestriction. However, the lack of present or fossil populations of Hapalogastrinae in the Atlantic suggests that they did not pass through the Arctic Ocean, or through the Panama seaway before it closed 3.5-13 Ma (Schneider \& Schmittner, 2006). In this case, distribution-limiting barriers (geographical or physiological) must have isolated the North Pacific population since the divergence of the family. Dates for the divergence of lithodids from their most recent ancestors suggest that North Pacific populations have existed for 13-25 Myr (Cunningham et al., 1992). The only fossil evidence is from a deep-sea lithodid of the genus Paralomis, $10 \mathrm{Ma}$ in New Zealand (Feldmann, 1998). Without substantial fossil evidence or modern molecular estimates (McLaughlin et al., 2007), it is 
difficult to speculate further, but this study may eventually help to impose some limiting dates on the timescale of divergence in this family.

\section{Vertically migrating Lithodinae}

The lithodine genus Paralithodes is known experimentally to have increased larval mortality above $15^{\circ} \mathrm{C}$ (Kurata, 1960; Shirley \& Shirley, 1989). Unlike the small Hapalogastrinae, which have uncalcified abdomens and a range tied to protective kelp forests or rocks (Zaklan, 2002a), Paralithodes is anatomically capable of migrating very large distances. Their sampled range (Table 1) indicates that they are able to survive in waters deep enough to avoid seasonally influenced temperature fluctuations, but their planktotrophic larval phase links them to surface waters. In these circumstances, range expansion south of the coastal $15^{\circ} \mathrm{C}$ isotherm would not be possible.

\section{Submergence}

Each of the three deep-sea lineages (Glyptolithodes and Paralomis are very similar, and will be treated as one lineage) had distinct distributional characteristics, and the molecular phylogeny (Fig. 2) suggested that the three radiations were independent.

Several advantages may be associated with an increase in habitat depth, including a lowered metabolic energy consumption, and an increase in environmental stability especially in areas where surface waters are affected by seasonal fresh-water influx (Shirley \& Shirley, 1989).

In the deeper regions of the sea, there is increased difficulty in coordinating spawning with favourable surface temperature, as the cues are more remote (Stevens, 2006). A (at least) facultative lecithotrophic larval mode of development allows independence from seasonal variations in primary productivity. This enables tolerance of the protracted development times associated with cold waters in polar and deep-sea environments (Shirley \& Zhou, 1997). Experimentally determined full lecithotrophy is known from the genera Lithodes and Paralomis (Anger, 1996; Shirley \& Zhou, 1997; Calcagno et al., 2003, 2005; Kattner et al., 2003; Watts et al., 2006) in geographically disparate species. There are no records of lifehistory in the abyssal genus Neolithodes; however, the reduced fecundity and increased egg size expected as corollaries of lecithotrophy are found in all studied species of this genus (Morley et al., 2006; S. Hall, personal observation). This higher maternal investment might have become a feature of deep-sea lithodids because of the mismatch between prolonged embryo/larval developmental times and the short pulses of surface primary production (Thatje et al., 2005; Morley et al., 2006).

\section{Emergence}

Polar emergence is a trend within species of both Paralomis and Lithodes genera (Fig. 3). There is no such trend in the genus Neolithodes, possibly because of its abyssal specializations. In Patagonia, where members of the deep-sea genera of Lithodinae have emerged into a subtidal or intertidal environment (Lovrich et al., 2002), they retain full and apparently obligatory lecithotrophy in all larval stages (Kattner et al., 2003; Saborowski et al., 2006). The possibility of a transition from larval lecithotrophy back to planktotrophy is widely rejected by larval ecologists and physiologists (Strathman, 1978). If this viewpoint is accepted, then the observation of lecithotrophy in P. granulosa and L. santolla represents further support for a deep-sea emergence pattern in the Southern Hemisphere, and furthermore refutes the possibility that North Pacific populations originated in the deep sea.

The thermal structure of oceans may play an important role in the changing patterns of lithodid biogeography. This could be an increasingly important phenomenon with regard to climate change and oscillations in oceanic upwelling zones (Thatje et al., 2005).

Species of the genera Paralomis and Neolithodes are among the few anomuran taxa found at high latitudes in the Southern Ocean, and it seems likely that a history of deep-sea adaptation has been associated with their successful colonization of polar regions. In the Antarctic particularly, 'emerging lithodids' in the warmer seas have the potential to threaten the isolated shelf communities (Thatje et al., 2005; Aronson et al., 2007), which have evolved in the absence of crushing predators (Feldmann \& Tshudy, 1989; Crame, 1994). Here, where lithodids seem to be living at the lower boundary of their physiological threshold, even a slight increase in temperature might open up new habitats.

\section{CONCLUSIONS}

Distributional traits, shared between paraphyletic members of the Lithodinae and the Hapalogastrinae, suggest an ancestral population of shallow-water anomurans in the North-East Pacific Ocean that was cold-eurythermal. Some shallow-water populations of Lithodidae (those with no ancestral link to the deep sea) are tied to waters north of $30^{\circ} \mathrm{N}$, because of the restricted thermal tolerance of larval stages. At least three lineages from within the subfamily Lithodinae have an expanded bathymetric range and widespread distribution. These groups are limited to greater depths, except at high latitudes, and have narrower adult temperature tolerance as an adaptation to the cold stenothermal deep sea. Lithodids of the subfamily Lithodinae have the potential to expand into previously uninhabitable regions of polar seas if water temperatures continue to increase, with potentially devastating effects for the Antarctic shelf fauna.

\section{ACKNOWLEDGEMENTS}

This work was supported by the Marine Biodiversity and Ecosystem Functioning Network of Excellence MarBEF (contract no. GOCE-CT-2003-505446) of the FP6, through a NERC $\mathrm{PhD}$ studentship to S.H., and through a Royal Society 
Research Grant (R2/2006) to S.T. We would like to thank the curators of the museums that S.H. visited as part of this study for their extensive help and comments. Special thanks go to Paul Clark of the Natural History Museum (NHM), London; Régis Cleva, Muséum National d'Histoire Naturelle (MNHN), Paris; Michael Türkay, Senkenberg Museum, Frankfurt; Rafael Lemaitre and Karen Reed, United States National Museum of Natural History (USNM), Washington; Enrique Macpherson, Institut de Ciències del Mar (ICM), Barcelona. We acknowledge the substantial contribution to this work from data provided by S.D. Zaklan's review of the family Lithodidae. We thank Paul Tyler, Rodney Feldman and another anonymous reviewer for their helpful comments on the manuscript.

\section{REFERENCES}

Abelló, P. \& Macpherson, E. (1991) Distribution patterns and migration of Lithodes ferox (Filhol), (Anomura, Lithodidae) off Namibia. Journal of Crustacean Biology, 11, 261-268.

Andriashev, A.P. (1986) Review of the snailfish genus Paraliparis (Scorpaeniformes: Liparididae) of the Southern Ocean. Theses Zoologicae, 7, 1-204.

Anger, K. (1996) Physiological and biochemical changes during lecithotrophic larval development and early juvenile growth in the northern stone crab, Lithodes maja (Decapoda: Anomura). Marine Biology, 126, 283-296.

Arana, E.P. \& Retamal, M.A. (1999) New distribution of Paralomis birsteini Macpherson, 1988 in Antarctic waters (Anomura, Lithodidae, Lithodinae). Investigaciones Marinas Universidad Catolica de Valparaíso, 27, 101-110.

Armistead, C., Bowers, F., Gish, R., Harrington, G., Jones, W., Kruse, G.H., Mabry, K., Morrison, R., Otto, R.S., Palach, B., Stevens, B.G., Wilson, E., Witherell, D. \& Zheng, J. (2000) Crab SAFE. Stock assessment and fishery evaluation report for the King and Tanner crab fisheries of the Bering Sea and Aleutian Islands. North Pacific Fishery Management Council, Ancorage, AK.

Aronson, R.B., Thatje, S., Clarke, A., Peck, L.S., Blake, D.B., Wilga, C.D. \& Seibel, B.A. (2007) Climate change and invasibility of the Antarctic benthos. Annual Review of Ecology Evolution and Systematics, 38, 129-154.

Bouvier, E.L. (1895) Recherches sur les affinités des Lithodes et des Lomis avec les Pagurides. Annales des Science Naturelles, Zoologie, 7, 157-213.

Bouvier, E.L. (1896) Sur la classification des Lithodinés et sur leur distribution dans les oceans. Annales des Science Naturelles, Zoologie, 8, 1-46.

Briggs, J.C. (2003) Marine centres of origin as evolutionary engines. Journal of Biogeography, 30, 1-18.

Calcagno, J.A., Thatje, S., Anger, K., Lovrich, G.A. \& Kaffenberger, A. (2003) Changes in biomass and chemical composition during lecithotrophic larval development of the southern stone crab, Paralomis granulosa (Jacquinot). Marine Ecology Progress Series, 257, 189-196.
Calcagno, J.A., Lovrich, G.A., Thatje, S., Nettelmann, U. \& Anger, K. (2005) First year growth in the lithodids Lithodes santolla and Paralomis granulosa reared at different temperatures. Journal of Sea Research, 54, 221-230.

Crain, J.A. \& McLaughlin, P.A. (2000) Larval and early juvenile development in the Lithodidae (Decapoda: Anomura: Paguroidea) reared under laboratory conditions. Invertebrate Reproduction and Development, 37, 113-127.

Crame, J.A. (1994) The evolutionary history of Antarctica. Antarctic science - global concerns (ed. by G. Hempel), pp. 188-214. Springer, Berlin.

Cunningham, C.W., Blackstone, N.W. \& Buss, L.W. (1992) Evolution of king crabs from hermit crab ancestors. Nature, 355, 539-542.

Feldmann, R.M. (1998) Paralomis debodeorum, a new species of decapod crustacean from the Miocene of New Zealand: first notice of the Lithodidae in the fossil record. New Zealand Journal of Geology and Geophysics, 41, 35-38.

Feldmann, R.M. \& Tshudy, D.M. (1989) Evolutionary patterns in macrurous decapod crustaceans from Cretaceous to early Cenozoic rocks of the James Ross Island region, Antarctica. Origins of the Antarctic biota (ed. by J.A. Crame), pp. 183195. Special Publication No. 47, Geological Society, London.

Forward, R.B. (1987) Larval release rhythms of decapod crustaceans: an overview. Bulletin of Marine Science, 41, 165-176.

Goshima, S., Ito, K., Wada, S., Shimizu, M. \& Nakao, S. (1995) Reproductive biology of the stone crab Hapalogaster dentata. Crustacean Research, 24, 8-18.

Harrison, M.K. \& Crespi, B.J. (1999) Phylogenetics of Cancer crabs (Crustacea: Decapoda: Brachyura). Molecular Phylogenetics and Evolution, 12, 186-199.

Jorgensen, L.L., Manushin, I., Sundet, J.H. \& Birkley, S.R. (2005) The intentional introduction of the marine red king crab Paralithodes camtschaticus into the Southern Barents Sea. ICES Cooperative Research Project No. 277, Copenhagen.

Kattner, G., Graeve, M., Calcagno, J., Lovrich, G.A., Thatje, S. \& Anger, K. (2003) Lipid, fatty acid and protein utilization during lecithodrophic larval development of Lithodes santolla (Molina) and Paralomis granulosa (Jaquinot). Journal of Experimental Marine Biology and Ecology, 292, 61-74.

Klages, M., Gutt, J., Starmans, A. \& Bruns, T. (1995) Stone crabs close to the Antarctic continent: Lithodes murrayi (Henderson, 1888). Polar Biology, 15, 73-75.

Kurata, H. (1960) Studies on the larva and post-larva of Paralithodes camtschatica III. The influence of temperature and salinity on the survival and growth of the larva. Bulletin of the Hokkaido Regional Fisheries Research Laboratory, 21, 9-14.

Locarnini, R.A., Mishonov, A.V., Antonov, J.I., Boyer, T.P. \& Garcia, H.E. (2006) World Ocean Atlas 2005, Vol. 1: Temperature. NOAA Atlas NESDIS 61 (ed. by S. Levitus). US Government Printing Office, Washington, DC. 
Lovrich, G.A. \& Thatje, S. (2006) Reproductive and larval biology of the sub-Antarctic hermit crab Pagurus comptus reared in the laboratory. Journal of the Marine Biological Association of the United Kingdom, 86, 743-749.

Lovrich, G.A. \& Vinuesa, J.H. (1993) Reproductive biology of the 'false southern king crab' (Paralomis granulosa, Lithodidae) in the Beagle Channel, Argentina. Fisheries Bulletin, 91, 664-675.

Lovrich, G.A. \& Vinuesa, J.H. (1999) Reproductive potential of the lithodids Lithodes santolla and Paralomis granulosa (Anomura, Decapoda) in the Beagle Channel, Argentina. Scientia Marina, 63, 355-360.

Lovrich, G.A., Perroni, M., Vinuesa, J.H., Tapella, F., Chizzini, A. \& Romero, M.C. (2002) Occurrence of Lithodes confundens (Decapoda: Anomura) in the intertidal of the southwestern Atlantic. Journal of Crustacean Biology, 22, 894-902.

Macpherson, E. (1988) Revision of the family Lithodidae Samouelle, 1819 (Crustacea, Decapoda, Anomura) in the Atlantic Ocean. Zoological Monographs, Vol. II. Institut de Cièncias del Mar, Barcelona.

Makarov, V.V. (1962) Fauna of the USSR (Crustacea). Israel Program for Scientific Translations, Jerusalem.

McLaughlin, P.A., Lemaitre, R. \& Sorhannus, U. (2007) Hermit crab phylogeny: a reappraisal and its "fall-out". Journal of Crustacean Biology, 27, 97-115.

Miquel, J.C., Arnaud, P.M. \& Dochi, T. (1985) Population structure and migration of the stone crab Lithodes murrayi in the Crozet Islands, sub-Antarctic Indian Ocean. Marine Biology, 89, 263-269.

Morley, S.A., Belchier, M., Dickson, J. \& Mulvey, T. (2006) Reproductive strategies of sub-Antarctic lithodid crabs vary with habitat depth. Polar Biology, 29, 581-584.

Nakanishi, T. (1981) The effect of temperature on growth, survival and oxygen consumption of larvae and post larvae of Paralithodes brevipes. Bulletin of the Japanese Sea Region Fisheries Research Laboratory (Nissuiken Hokoku), 32, 49-56.

Nakanishi, T. (1985) The effects of the environment on the survival rate, growth and respiration of eggs, larvae and post larvae of king crab (Paralithodes camtschatica). International King Crab Symposium, pp. 167-185. Alaska Sea-Grant Program, Ankorage, AK.

Orlov, Y. \& Ivanov, B. (1978) On the introduction of the Kamchatka king crab Paralithodes camtschatica (Decapoda: Anomura: Lithodidae) into the Barents Sea. Marine Biology, 48, 373-375.

Paul, A.J. \& Paul, J.M. (2001) The reproductive cycle of golden king crab Lithodes aequispinus (Anomura: Lithodidae). Journal of Shellfish Research, 20, 369-371.

Perez-Losada, M., Bond-Buckup, G., Jara, C.G. \& Crandall, K.A. (2004) Molecular systematics and biogeography of the southern South American freshwater 'crabs' Aegla (Decapoda: Anomura: Aeglidae) using multiple heuristic tree search approaches. Systematic Biology, 53, 767-780.

Raso, J.E.G., Manjon-Cabeza, M.E., Ramos, A. \& Olaso, I. (2004) New record of Lithodidae (Crustacea Decapoda
Anomura) from the Antarctic (Bellingshausen Sea). Polar Biology, 28, 642-646.

Raupach, M.J., Mayer, C., Malyutina, M. \& Wägele, J.-W. (2008) Multiple origins of deep-sea Asellota (Crustacea: Isopoda) from shallow waters revealed by molecular data. Proceedings of the Royal Society B: Biological Sciences, 276, 799-808.

Reid, W., Watts, J., Clarke, S., Belchier, M. \& Thatje, S. (2007) Egg development, hatching rhythm and moult patterns in reared Paralomis spinosissima (Decapoda: Anomura: Paguroidea: Lithodidae) from South Georgia waters (Southern Ocean). Polar Biology, 30, 1213-1218.

Saborowski, R., Thatje, S., Calcagno, J.A., Lovrich, G.A. \& Anger, K. (2006) Digestive enzymes in the ontogenetic stages of the southern king crab, Lithodes santolla. Marine Biology, 149, 865-873.

Schneider, B. \& Schmittner, A. (2006) Simulating the impact of the Panamanian Seaway closure on ocean circulation, marine productivity and nutrient cycling. Earth and Planetary Science Letters, 246, 367-380.

Shirley, T.C. \& Shirley, S.M. (1989) Temperature and salinity tolerances and preferences of red king crab larvae. Marine Behaviour and Physiology, 16, 19-30.

Shirley, T.C. \& Zhou, S.J. (1997) Lecithotrophic development of the golden king crab Lithodes aequispinus (Anomura: Lithodidae). Journal of Crustacean Biology, 17, 207-216.

Stevens, B.G. (2006) Timing and duration of larval hatching for blue king crab Paralithodes platypus, Brandt, 1850 held in the laboratory. Journal of Crustacean Biology, 26, 495-502.

Stone, R.P., Oclair, C.E. \& Shirley, T.C. (1992) Seasonal migration and distribution of female red king crabs in a Southeast Alaskan estuary. Journal of Crustacean Biology, 12, $546-560$.

Strathman, R.L. (1978) The evolution and loss of feeding stages in marine invertebrates. Evolution, 32, 894-906.

Swofford, D.L. (2000) PAUP*. Phylogenetic analysis using parsimony ( ${ }^{*}$ and other methods). Version 4. Sinauer Associates, Sunderland, MA.

Thatje, S. (2004) Reproductive trade offs in benthic decapod crustaceans of high southern latitudes: tolerance of cold and food limitation. Berichte zur Polar- und Meeresforschung, 483, 1-183.

Thatje, S., Calcagno, J.A., Lovrich, G.A., Sartoris, F.J. \& Anger, K. (2003) Extended hatching periods in the sub-Antarctic lithodid crabs Lithodes santolla and Paralomis granulosa (Crustacea: Decapoda: Lithodidae). Helgoland Marine Research, 57, 110-113.

Thatje, S., Anger, K., Calcagno, J.A., Lovrich, G.A., Pörtner, H.O. \& Arntz, W.E. (2005) Challenging the cold: crabs reconquer the Antarctic. Ecology, 86, 619-625.

Thatje, S., Hall, S., Tyler, P.A., Hauton, C. \& Held, C. (2008) Encounter of Paralomis birsteini on the continental slope off Antarctica, sampled by ROV. Polar Biology, 31, 11431148.

Vinuesa, J.H., Ferrari, L. \& Lombardo, R.J. (1985) Effect of temperature and salinity on larval development of southern king crab (Lithodes antarcticus). Marine Biology, 85, 83-87. 
Watts, J., Thatje, S., Clarke, S. \& Belchier, M. (2006) A description of larval and early juvenile development in Paralomis spinosissima (Decapoda: Anomura: Paguroidea: Lithodidae) from South Georgia waters (Southern Ocean). Polar Biology, 29, 1028-1038.

Zaklan, S.D. (2002a) Evolutionary history and phylogeny of the family Lithodidae. $\mathrm{PhD}$ Thesis, University of Alberta, Edmonton.

Zaklan, S.D. (2002b) Review of the family Lithodidae (Crustacea: Anomura: Paguroidea): distribution, biology and fisheries. Crabs in cold water regions: biology, management and economics (ed. by A.J. Paul, E.G. Dawe, R. Elner, G.S. Jamieson, G.H. Kruse, R.S. Otto, B. Sainte-Marie, T.C. Shirley and D. Woodby), pp. 751-845. Alaska Sea Grant College Program, Fairbanks, AK.

Ziegler, T.A. \& Forward, R.B. (2005) Larval release rhythm of the mole crab Emerita talpoida (Say). Biological Bulletin, 209, 194-203.

\section{SUPPORTING INFORMATION}

Additional Supporting Information may be found in the online version of this article:
Appendix S1 GenBank accession numbers of sequences used in Figure 2, and details of primers used in this study.

Please note: Wiley-Blackwell is not responsible for the content or functionality of any supporting materials supplied by the authors. Any queries (other than missing material) should be directed to the corresponding author for the article.

\section{BIOSKETCHES}

Sally Hall is a $\mathrm{PhD}$ student at the National Oceanography Centre, Southampton. She is studying aspects of the evolution and radiation of the family Lithodidae.

Sven Thatje is an evolutionary ecologist studying the evolutionary history of life in extreme environments. He is a lecturer at the University of Southampton's School of Ocean and Earth Science at the National Oceanography Centre, Southampton.

Editor: Alistair Crame 